\title{
Expert System Application of Forward Chaining and Certainty Factors Method for The Decision of Contraception Tools
}

\author{
Dwi Arief Prambudi ${ }^{1, *}$, Catur Edi Widodo ${ }^{2}$, and Aris Puji Widodo ${ }^{3}$ \\ ${ }^{1}$ Magister Program of Information System, School of Postgraduate Studies, Diponegoro University, Semarang - Indonesia 50242 \\ ${ }^{2}$ Department of Physics, Faculty of Science and Mathematics, Diponegoro University, Semarang - Indonesia 50275 \\ ${ }^{3}$ Department of Computer Science, Faculty of Science and Mathematics, Diponegoro University, Semarang - Indonesia 50275
}

\begin{abstract}
The choice of contraceptive tools is not an easy thing because the risks or effects will give impact on the body that never using it previously. in the other side, there is no contraception always suit for everybody because the circumstances of each body is different, so the extens ive knowledge must be needed to know the advantages and disadvantages of each contraceptive tools then adjusted to the user's body. The expert system for contraceptive tools uses Forward Chaining search method combined with Certainty Factors Method. These method value the patient's indication. The Expert system gives the output data which define the kind of tool uses of the patient. the results obtained will be able to help people to find indications that lead to appropriate contraceptive tools and advice or suggestions about these tools. The success rate of the contraceptive tools decision experienced by experienced by the user by using forward chaining combined with the CF computation method is also influenced by the number of indication criteria selected by the user. Based on testing that has been done, expert system contraception tools has accuracy level equal to $75 \%$.
\end{abstract}

\section{Introduction}

To suppress the rapid population growth, can be done with a variety of actions, such as promoting family planning programs to limit the number of children in a family to be built later, including in planning time and the number of children born to each child in the future [1]. The only way to set the number and time of pregnancy is through the use of contraceptives. Steps for setting up the Nativity or postpone pregnancy needed contraceptives in order toward the prosperous and happy families. Many of the undesirable pregnancy, unplanned pregnancy happen because these couples do not use preventive of pregnancy, and partly to use contraceptives but not correct usage.

Choosing birth control is not an easy thing because the risk or effects that affect to the body will not be known for have not used it. In addition there is no contraceptive are always suitable for everyone because of the situation and condition of the body is always different, so the extensive knowledge must be needed. Risk factors in the choice of contraceptives is very necessary to be considered. Factors that affect the frequency of sexual intercourse, such as ease of returns pregnant again, side effects to lactation, and the effects of the contraceptive in the future. In addition to the foregoing consideration of contraception also is based on the age, the use of contraceptives before, the period of use of contraception, effectiveness, security, frequency of use, menstrual periods, health disorders, breast feeding childbirth, types of contraceptives, as well as the willingness and ability to do a regular contraceptive. As an example of the use of the contraceptive pill, Minipills are highly effective (98.5\%) for use in nursing mothers when used correctly and consistently. But the effectiveness of the contraceptive pill will be reduced when breast feeding, and the effectiveness of the mini pill would be lower if the use of the mini pill is consumed along with tuberculosis or epilepsy. The side effects caused from the use of the mini pill menstrual disorders such as increased weight gain, pain in the breast, nausea, dizziness, bloating and the incidence of dermatitis or Acne [2].

One of the researches associated with risk factors such as the analysis of the negative effects of the use of contraceptive implants on the lives of individuals [3]. There are many methods that can be used in the expert system, including method of forward chaining. Related research forward chaining has been widely performed by some researchers previously, one of which implementation method of forward chaining rule-based expert systems on classification of nutritional status toddler [4].

Other studies relating to contraception is using expert system to help diagnose ectopic pregnancy with the use of a factor of certainty to get quality answers from each patient [5]. The selection of efficient contraception can be judged from the cost of contraception in protecting pregnancy per year of its use from a pair. Then the election effectively contraceptives should be based on

* Corresponding author: dwiariefprambudi@gmail.com or dwiariefprambudi@student.undip.ac.id 
consideration of the effectiveness and risks of each type of contraception is based on the level of its success.

\section{Literature review}

Development of expert system applied in many different areas of life. Several studies from different fields has ever done about expert system, introduce a visual basic expert system to help graduate students in the diagnosis and treatment. The system used to help graduate students in the diagnosis and treatment of oral ulcers are known to most common to the rarest [6] . In the health field has been widely developed an expert system to diagnose the disease diabetes complications mikrovaskular using cereal knowledge [7]. In the field of industry, expert system can be used to identify the location or any damage to the electronic systems, industrial systems, or on other systems. Expert system can also be used for optimization of the grinding force adjustments to get maximum results [8].

Related research Forward chaining rule-based pun has been much done by some earlier researchers, such as the implementation of Forward chaining on a complex interaction of social response on autistic children. In this study, a few examples of autistic children are taught how to receive the response in the process of sharing inducing [9].

There are also many research about birth control, such as a decision support system in the selection of an alternative birth control using fuzzy logic [10]. Other research trying to integrate expert system with analytical hierarchy process to determine the right birth control for each individual. The results in the form of information about contraception are recommended [11]. Research related to risk factors such as the analysis of the negative effects of the use of contraceptive implants on the life of the user [12]. research related to risk factors against the teenager on the use of contraception i.e. the existence of qualitative research that influences the selection of contraception in teen age [13]. The presence of risk factors posed on the use of oral contraception tool against cervical cancer diagnosis on the user [14]. The risk of the use of hormonal contraceptives against the incidence of cervical cancer suffered by users who performed research for a year from 2006 to 2007 [15].

\subsection{Expert system}

Expert system is a computer software that has a knowledge base for the specific domain and use reasoning inference resembles that of an expert in solving problems and finding solutions [16]. In General, the expert system is a system that attempted to adopt human knowledge to a computer that is designed to model the ability to resolve problems such as befits an expert. With this expert system, any layman can solve the problem or just simply looking for actual quality information can only be obtained with the help of experts in their field. Expert system will also be able to assist the activities of the experts as an experienced Assistant and has the required knowledge.
An expert with expert system has a lot of difference. Comparison of ability between an expert with an expert system as shown in table 1 [17].

Table 1. Comparison of experts and expert system (Durkin, 1994)

\begin{tabular}{|l|l|l|l|}
\hline No & Factor & Human expert & Expert sistem \\
\hline 1 & Time availability & workday & Anytime \\
\hline 2 & $\begin{array}{l}\text { Geographic } \\
\text { condition }\end{array}$ & Local/ certain & Anywhere \\
\hline 3 & perishable & Yes & No \\
\hline 4 & Performance & Variable & Consistent \\
\hline 5 & speed & Variable & Consistent \\
\hline 6 & cost & High & Affordable \\
\hline
\end{tabular}

\subsection{Forward chaining method}

An inference that connects a multiplication problem with solution called chain. A chain is sought or is bypassed or crossed from a problem to obtain the solution referred to as Forward Chaining. Another way of describing the forward chaining this is by reasoning from facts leading to the conclusion that there is from the facts.

In the advanced rules of reasoning are tested one by one in a specific order. The sequence may be either a sequence of rules of incorporation into the base rules or also other sequence determined by the user. Each time a rule is tested, the expert system will evaluate whether conditions are true or false. If the condition is true, then the rule is kept then the next rule is tested. Conversely, if conditions are wrong, it is not stored and the next rule is tested. This process would be repeated until the entire base of the rules tested with a variety of conditions. Advanced reasoning work with problems that started with the recording of the initial information and the final settlement to be achieved, then the whole process will be done sequentially. Figure 1 shows the process forward chaining

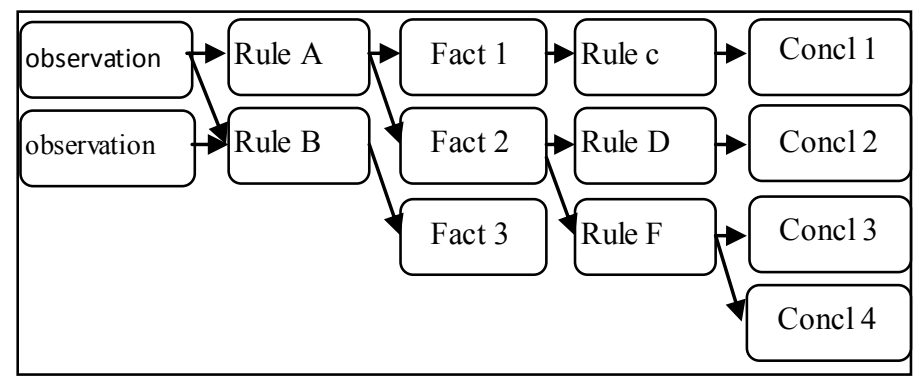

Fig. 1. Forward chaining method

\subsection{Certainty factors}

Expert system must be able to work in uncertainty [18] . Certainty factor is the way of the merger of trust and distrust in the single numbers. In certainty theory, qualitative data is represented as the degree of conviction. There are two steps in the qualitative data representations. The first step is the ability to express the degree of confidence in accordance with the methods. 
The second step is the ability to place and the degree of confidence in combines expert system. In expressing a degree of certainty, belief theory using a value called the $\mathrm{CF}$ to assumes degrees of belief an expert against a data. The CF introduced the concept of belief and disbelief. This concept was later formulated in the following basic formula:

$C F(H, E)=M B(H, E)-M D(H, E)$

Description:

$\mathrm{CF}(\mathrm{H}, \mathrm{E})$ : certainty factor of hypothesis $\mathrm{H}$ that is affected by symptoms

(evidence) E. CF Magnitude ranging between -1 to 1 .

A value of -1 indicates an absolute disbelief while a value of 1 indicates an absolute trust.

MB (H, E): the size of the increase in confidence (a Measure of Increased Belief) hypothesis $\mathrm{H}$ that is affected by symptoms of $\mathrm{e}$.

MD (H, E): the size of the increase of unbelief (a Measure of Disbelief Increased) hypothesis $\mathrm{H}$ that is affected by symptoms of e.

CF network shows confidence in a hypothesis based on some fact or symptoms in medicine. CF-positive meaningful facts supporting the hypothesis because MB $>$ MD.

$\mathrm{CF}=1$ means that the fact by definition proves a hypothesis. $\mathrm{CF}=0$ means one of two possibilities, namely the first $\mathrm{CF}=\mathrm{MB}-\mathrm{MD}=0$ both $\mathrm{MB}$ and $\mathrm{MD}$ is zero which means no facts. The second possibility is that the $\mathrm{MD}=\mathrm{MB}$ and both are not the same as zero which means that trust is deleted or removed by distrust. CF negative means that the facts indicate negation of the hypothesis because $\mathrm{MB}<\mathrm{MD}$. In other words, it is more reasonable to express distrust toward the hypothesis than believe it.

Specify parallel CF obtained from some premise on a rule. The magnitude of the $\mathrm{CF}$ sequential influenced by the $\mathrm{CF}$ for each premise and the operators of the premises. The formula of each operator can be seen as follows.

$$
\begin{array}{ll}
\mathrm{CF}(\mathrm{x} \text { and } \mathrm{y}) & =\operatorname{Min}(\mathrm{CF}(\mathrm{x}), \mathrm{CF}(\mathrm{y})) \\
\mathrm{CF}(\mathrm{x} \text { or } \mathrm{y}) & =\operatorname{Max}(\mathrm{CF}(\mathrm{x}), \mathrm{CF}(\mathrm{y})) \\
\mathrm{CF}(\operatorname{Not} \mathrm{x}) & =-\operatorname{CF}(\mathrm{x})
\end{array}
$$

The basic formula for the CF from the rule IF E THEN $\mathrm{H}$ is given by formula:

$\mathrm{CF}(\mathrm{H}, \mathrm{E})=\mathrm{CF}(\mathrm{E}, \mathrm{e}) * \mathrm{CF}(\mathrm{H}, \mathrm{e})$

Description:

CF (H, E): certainty factor hypotheses assuming the evidence uncertain, i.e. when the $\mathrm{CF}(\mathrm{E}, \mathrm{e})=1$

CF (E, e): certainty factor evidence $\mathrm{E}$ influenced by evidence $\mathrm{e}$

CF $(\mathrm{H}, \mathrm{e})$ : certainty factor hypothesis was influenced by evidence $\mathrm{e}$

If there are two rules that have the same hypothetical conclusions, then factor in the conviction of two rules combined with calculated confidence, namely:

CF CF (x) (y) (CF CF * (x) (y)), if (x) 0 CF and CF (y) 0

$\mathrm{CF}(\mathrm{x}, \mathrm{y})=(\mathrm{CF} C \mathrm{CF}(\mathrm{x})(\mathrm{y})) /(((\operatorname{Min}(\mathrm{CF}(\mathrm{x})|\vdash| \mathrm{CF}(\mathrm{y})))))$, one $(\mathrm{CF}$, $\mathrm{CF}$ (x) (y)) 0 (7)

$\mathrm{CF}(\mathrm{x})(\mathrm{CF}(\mathrm{y}) *(1 \mathrm{CF}(\mathrm{x})))$ if (x) 0 CF and CF (y) 0
$\mathrm{CF}$ is $\mathrm{CF}$ joint end of a prospective conclusions drawn. $\mathrm{CF}$ joint is required if a conclusion obtained from several rules at once. $\mathrm{CF}$ end of one rule with the other rules are combined to get the final value of the CF for the prospective conclusion.

\section{Method}

In this study were divided into several stages that are used to build an expert system application, starting from the stage of problem identification or analysis, knowledge acquisition and knowledge representation. In this study also used the method certainty factor to deal with the uncertainty of the results in the application of expert systems.

\subsection{Identify the problem and knowledge}

Making this expert system begins with determining the problem, in this case is to decide the appropriate contraception tools. It is very important to determine which will further the knowledge required in the system. The identification process begins from the knowledge acquisition of knowledge and continued with knowledge representation.

\subsection{Knowledge acquisition}

The acquisition of knowledge is a process to collect data knowledge will be a problem. In this study used two types of data obtained through different ways. The data used is primary data taken directly through the speakers in this case the experts that people be made the object of research to get information and data. Search primary data in this study will be conducted by interviewing an expert who was one of the doctors who are currently working in one hospital in Samarinda east Kalimantan. In this study also obtained information from the health books in the library, research journals and other literature that supports this research.

\subsection{Knowledge representation}

After the data collection process is completed, then the representation of data into the knowledge base and the rule base is then encoded, organized and described in draft form another so that a systematic form. The knowledge representation made into an expert system decides the appropriate contraception tools is to use the decision table and then formed a production rule.

\section{Results}

On the final assignment is examined about the use of contraceptives appropriate to each of its users. Basically any free user in selecting contraceptives. Users can use contraceptives is desirable. But any contraceptives have terms and conditions so that the tool is safe to use. The terms that will be used as factors in choosing contraception that is appropriate for each user 
Table 2 is a knowledge representation table of contracepstion tools.

Table 2.Table of knowledge representation.

\begin{tabular}{|c|c|c|c|c|c|c|c|c|c|}
\hline \multirow[b]{2}{*}{ no } & \multirow[b]{2}{*}{ Description Of Indication } & \multicolumn{8}{|c|}{ Tools } \\
\hline & & & & & & & & & \\
\hline 1 & In the reproductive age $(20-35)=0.85$ & $\mathrm{X}$ & & & & & & & \\
\hline 2 & Blood pressure less than $180 / 110 \mathrm{mmHg}=0.80$ & $\mathrm{X}$ & & & & & & & \\
\hline 3 & Smokers of all ages $=0.80$ & $\mathrm{X}$ & & & & & & & \\
\hline 4 & want long-term contraception $=1: 00$ & $\mathrm{X}$ & \begin{tabular}{|l|l}
$x$ & \\
\end{tabular} & $X$ & $X$ & $\underline{x}$ & $\begin{array}{ll}x \\
\end{array}$ & $\mathrm{x}$ & $\mathrm{X}$ \\
\hline 5 & want a short-term contraception $=1: 00$ & & \begin{tabular}{|l|l}
$x$ & \\
\end{tabular} & \begin{tabular}{l|l}
$X$ & 1 \\
\end{tabular} & $\mathrm{X}$ & $\bar{x}$ & & $\mathrm{x}$ & $\mathrm{X}$ \\
\hline 6 & Not taking estrogen $=0.80$ & $\mathrm{x}$ & & & & & & & \\
\hline 7 & breast cancer $=0.85$ & $\mathrm{X}$ & & & & & & & \\
\hline 8 & impaired lung $=0.75$ & $\mathrm{X}$ & & & & & & & \\
\hline 9 & Do not have a history of stroke $=0.80$ & $\mathrm{X}$ & & & & & & & \\
\hline 10 & Do not take your medicine and epilepsy tbc $=0.85$ & $\mathrm{X}$ & & & & & & & \\
\hline 11 & There is no inflammation of the genital $=0.95$ & & $\mathrm{X}$ & & & & & & \\
\hline 12 & Requires protection against sexually transmitted diseases $=0.90$ & & $\mathrm{X}$ & & & & & & \\
\hline 13 & No smoker $=0.90$ & & $\mathrm{X}$ & & & & & & \\
\hline 14 & Do not have a history of allergy to rubber $=0: 50$ & & $\mathrm{x}$ & & & & & & \\
\hline 15 & Do not have a history of poisoning shock syndrome $=0: 50$ & & $\mathrm{x}$ & & & & & & \\
\hline 16 & No experience infection in the urethra (the tube pee) $=0.65$ & & $\mathrm{X}$ & & & & & & \\
\hline 17 & Gender male $=0.85$ & & $\mathrm{X}$ & $\underline{x}$ & & & & & \\
\hline 18 & Age over 30 years $=0.85$ & & & $\underline{X}$ & & & & & \\
\hline 19 & Children over $2=0.90$ & & & $\underline{x}$ & & & & & \\
\hline 20 & $\begin{array}{l}\text { Understand and agree to vasectomy procedure and the } \\
\text { consequences }=0.65\end{array}$ & & & $\mathrm{X}$ & & & & & \\
\hline 21 & good psychological condition $=0.85$ & & & $\underline{X}$ & & & & & \\
\hline 22 & Age over 26 years $=0.90$ & & & & $X$ & & & & \\
\hline 23 & Post-childbirth $=0.90$ & & & & $\bar{X}$ & & & & \\
\hline 24 & Post-miscarriage $=0.90$ & & & & $\mathrm{X}$ & & & & \\
\hline 25 & $\begin{array}{l}\text { Understand and agree on the procedures and consequences } \\
\text { tubektomi }=0.85\end{array}$ & & & & $\mathrm{X}$ & & & & \\
\hline 26 & obese more than $140,90=0.90$ & & & & $\mathrm{X}$ & & & & \\
\hline 27 & hemoglobin less than $8=0.60$ & & & & $\mathrm{X}$ & & & & \\
\hline 28 & There is no ovulation (fertilization in the uterus) $=0.85$ & & & & 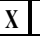 & & & & \\
\hline 29 & Do not want to be pregnant within a period of $1-5$ years $=0.80$ & & & & & $\mathrm{x}$ & & & \\
\hline 30 & The blood pressure $<180 / 110 \mathrm{mmHg}=0.90$ & & & & & $\mathbf{X}$ & & & \\
\hline 31 & suffered severe varicose $=0.65$ & & & & & $\mathrm{X}$ & & & \\
\hline 32 & Do not have a history of jaundice $=0.60$ & & & & & $\mathrm{x}$ & & & \\
\hline 33 & regular Haid $=0.60$ & & & & & $\mathrm{x}$ & & & \\
\hline 34 & There are nursing $=0.90$ & & & & & & $\mathrm{X}$ & & \\
\hline 35 & suffering from hiv $/ \mathrm{ims}=0.80$ & & & & & & $\mathrm{X}$ & & \\
\hline 36 & suffer from pelvic inflammatory $=0.75$ & & & & & & $\mathrm{X}$ & & \\
\hline 37 & infection in the genital $=0.85$ & & & & & & $\mathrm{x}$ & & \\
\hline 38 & No bleeding in the vagina $=0.60$ & & & & & & $\mathrm{x}$ & & \\
\hline 39 & anemic $=0.95$ & & & & & & & $\mathrm{x}$ & \\
\hline 40 & had a history of heart disease $=0.80$ & & & & & & & $\mathrm{X}$ & \\
\hline 41 & Not having migraine $=0.95$ & & & & & & & $\mathrm{x}$ & \\
\hline 42 & Approaching the age of menopause $=0.85$ & & & & & & & $\mathrm{x}$ & \\
\hline 43 & $\begin{array}{l}\text { Do not want more children but do not want to use safe contraception } \\
\qquad=0.95\end{array}$ & & & & & & & & $\mathrm{x}$ \\
\hline 44 & Mother postpartumover 6 weeks $=0.85$ & & & & & & & & $\mathrm{X}$ \\
\hline 45 & Mothers who have a history of hypertension $=0.55$ & & & & & & & & $\mathrm{X}$ \\
\hline
\end{tabular}

Using Forward Chaining and Certainty Factors then those factors will be made of the facts that are then processed by the existing rules so that it will yield a conclusion. Where is the conclusion in the form of contraceptive tools that can be used by any user. The results obtained by each user can be more than one type of contraception. So that the user can select the safe contraceptives to suit each user. Because according to the medical rules, users are welcome to choose which tools will be used. While only an expert help in choosing birth control.

The following list of contraceptives that are used:

1. P01 The contraceptive pill

2. P02 Condoms

3. P03 Vasectomy

4. P04 Tubektomi

5 P05 norplant

6 P06 Iud.

7. P07 Contraception hypodermic/ injection

8. P07 Implants

\subsection{Handling uncertainty}

In this study used a method certainty factor (CF) for the treatment of the uncertainty of the expert system. In the processing of data after their parameters, the next step is to create a rule that will be used in the expert system, after making the rules, then making inference engine with forward chaining methods as search stages and methods of the CF as the stage of the weighting. Examples of the application of the method of certainty factor in a case where an existing assumptions

In this expert system, the value obtained from the certainty factor $\mathrm{CF}$ and $\mathrm{CF}$ expert users. $\mathrm{CF}$ value obtained when users perform diagnostics on a $\mathrm{CF}$ specialist symptoms while the value given to a disease in a rule (rule) by using the AND operator in any rule made. Note the State is represented by a variable number 4, 1, 2, 3, 6, 7, 8 (relation 1) assuming that all circumstances are met (experienced by the patient).

If known cf $4=1.00,1=0.85,2=0.80,3=0.80,6=$ $0.80,7=0.85,8=0.75 \mathrm{cf}$ expert relationship $1=0.80$ then calculated the value of cf conclusion With the following steps:

1. Calculate the cf parallel relations 1

CF parallel relation 1: $\max (\mathrm{cf} 4, \mathrm{cf} 1, \mathrm{cf} 2, \mathrm{cf} 3, \mathrm{cf}$ $6, \operatorname{cf} 7, \operatorname{cf} 8)$

$: \max (1.00,0.85,0.80,0.80,0.80,0.85,0.75)$

$: 1.00$

2. Calculate the $\mathrm{cf}$ sequensial relation 1

CF sequensial of 1: parallel relations relations $1 *$ cf expert relationship 1

$: 1.00 * 0.80$

$: 0.80$

From the above calculation means of 0.80 percentage magnitude, that means producing $80 \%$.

\subsection{Examination systems}

System testing is performed to find out the extent success of expert system that has been built. The process of testing is done by evaluating the input and output that is generated by the application. This phase is carried out by field testing involving related experts (in this case the 
doctor or tocologist). Testing with experts performed a number of times with the intention of enabling an application able to be corrected as early as possible. Experts try to direct the system created by selecting symptoms from the system then check if diagnoze are produced accordingly and not distorted. After testing then proceed with validation as the process of testing the performance or accuracy against the example given during the process of testing is in progress. Stage of the validation process is carried out after the test was given, next the application is tested with another data. The purpose of validation is done in order to find out the extent of which the application is able to predict the values of the output and input values are given. The following equation validation.

Validation $(\%)=\left(\frac{A}{B}\right) \times 100 \%$

From the equation 2, $\mathrm{A}$ is the amount of data the same estimation results with the target, and B is the number of target data.

The equation will be applied at the time of calculating the level of accuracy in deciding application of contraception tools.

The application level test results fault detection of the tools, there are 15 of the 20 testing appropriate test. So that the application has a success rate of the contraception tools decision by $75 \%$.

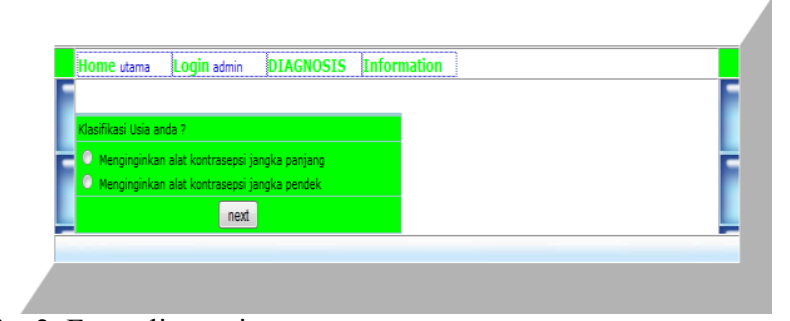

Fig. 2. Form diagnosis

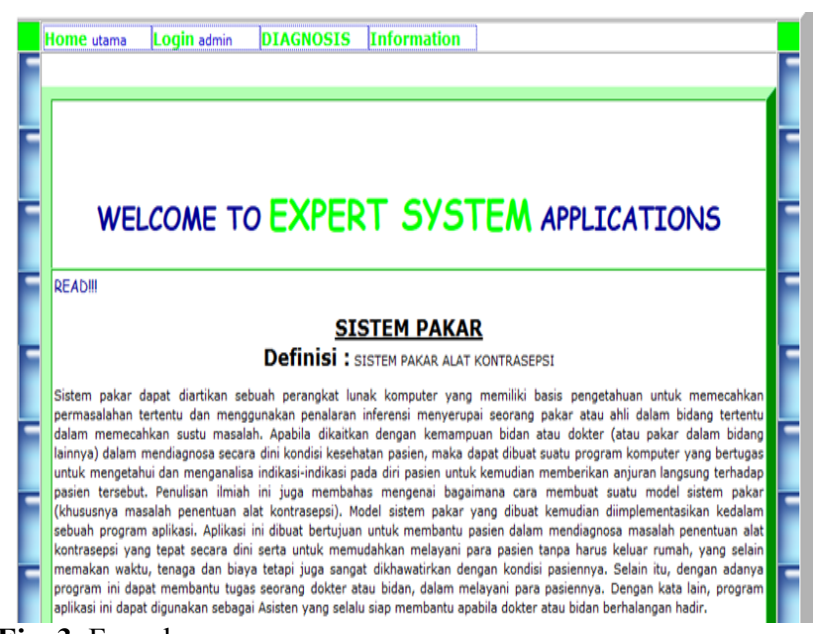

Fig. 3. Form home

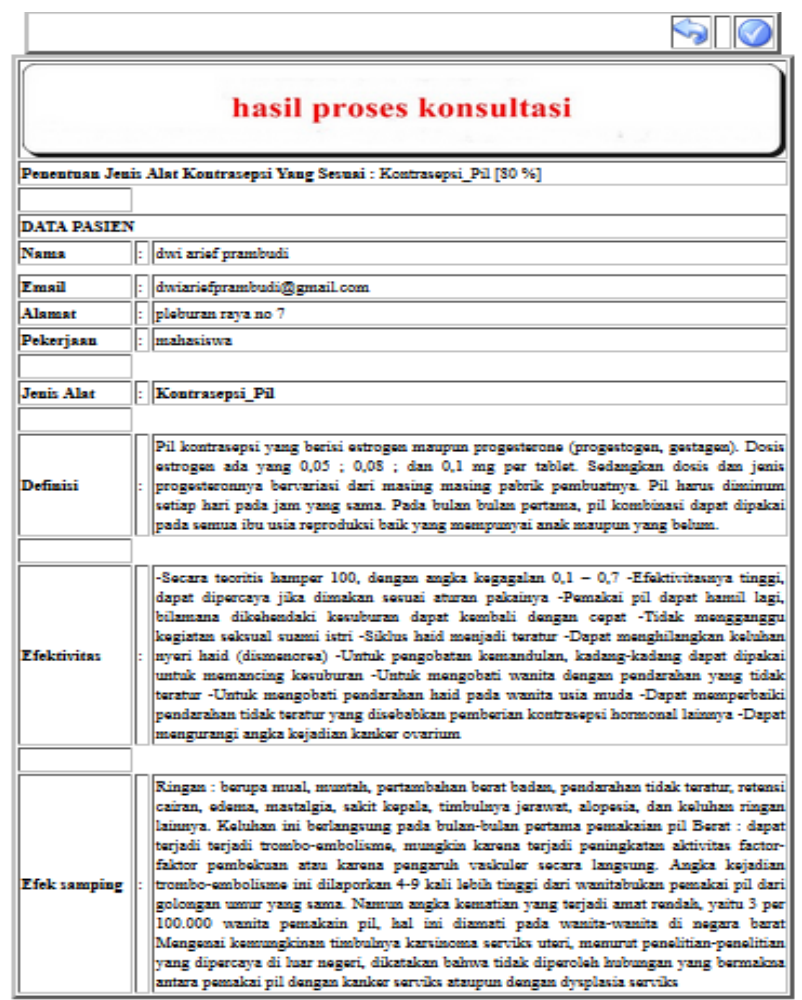

Fig. 4. Final calculation result

\section{Conclusion}

From a series of research methodology, analysis and discussion design of a system that has been done then it can be drawn the conclusion, has produced an application expert system for deciding the appropriate contraception tools is built using web-based method of forward chaining and certainty factors, using the programming language PHP and the MySQL database, which is a work based on user selected symptoms are then processed by the system so that it generates output in the form of the name tools, definition of tools, risk factors, examples of tools pictures, the percentage of confidence handling solutions diagnosis and tools.

Based on the testing that has been done the application expert system of the decision of contraception tools has an accuracy rate of $75 \%$.

\section{References}

1. Y. E. Chan, H. K. Ma, E. T. Chan, H. Y. Chen, and T. Y. Chen, (1995). International Journal of Computer Science Vol. 24, 293-298, (1995)

2. S.N. Mulyani, Keluarga Berencana dan Alat Kontrasepsi, Nuha Medika ; Yogyakarta, (2013)

3. E . S. Watkins, Journal J Womes Hist, 88-111, (2013).

4. N. Suhati, Implementasi Metode Forward chaining Berbasis Aturan Pada Sistem Pakar Klasifikasi Status Gizi Balita, thesis, Universitas Diponegoro, Semarang, (2015) 
5. G. Astuti, Sistem Pakar Pendiagnosis Kehamilan Ektopik, thesis, Universitas Gajah Mada, Yogyakarta, (2004)

6. S. A. Ali, and H. I. Saudi, (2014), Tanta Dental Journal Vol. 11, 42-46, (2014)

7. T.L.T. Nguyen, and N.V. Do, 2013, IJCSI Vol. 10, 308-316, (2013)

8. L. Rubio, M. D. Sen, A. P. Longstaff, and S. Fletcher, (2013). Journal Expert Systems with Applications Vol. 40, 2312-2322, (2013)

9. J. A. DeQuinzio, D. B. Townsend, and C. L. Poulson, (2008), Research in Autism Spectrum Disorders Vol. 2 264-275, (2008)

10. D.R. Wardhani, Sistem Pendukung Keputusan Dalam Penentuan Alat Kontrasepsi Untuk Keluarga Berencana Dengan Pemodelan Logika Fuzzy, seminar nasional, Stimik Amikom, Yogyakarta, (2014)

11. W. Priharyanti, Sistem Penunjang Keputusan Pemilihan Alat Kontrasepsi, thesis, Universitas Indonesia, Depok, (2013)

12. E . S. Watkins, Journal J Womes Hist, 88-111, (2013).
13. A.J. Hoopes, K. Gilmore, and K.R. Ahrens,. Journal of Pediatric and Adolescent Gynecology, Vol. 10, 164-259, (2015)

14. P . Lesmana, Faktor Risiko Pemakaian Alat Kontrasepsi Oral, Merokok,Dan Karakteristik Penderita Terhadap Kejadian Kanker Leher Rahim Di Rsd Dr. Soebandi Jember, Skripsi , Universitas Negeri Jember, Jember, (2011)

15. D . S. Tira, Risiko Jumlah Perkawinan, Riwayat Abortus, Dan Pemakaian Alat Kontrasepsi Hormonal Terhadap Kejadian Kanker Serviks Di Rumah Sakit Pelamonia Makassar Tahun 2006 2007, thesis , Universitas Nusa Cendana, Kupang, (2008)

16. F. Aziz, Belajar Sendiri Pemrograman Sistem Pakar, Elex Media Komputindo, Jakarta, (1994)

17. J. Durkin, Expert Systems: Design and Development, Macmillan Coll Div, , New York, (1994)

18. Kusrini, Sistem Pakar Teori \& Aplikasi. Andi ,Yogyakarta, (2006) 